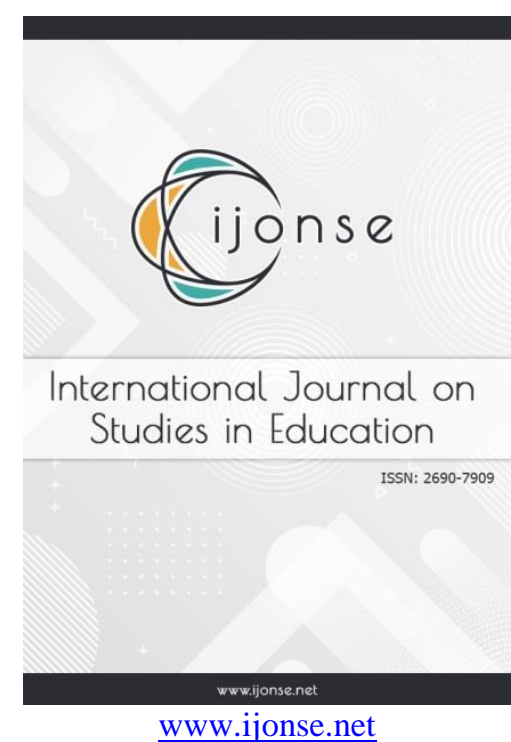

\title{
Online Education: Benefits, Challenges and Strategies During and After COVID-19 in Higher Education
}

\author{
Pitambar Paudel \\ Tribhuvan University, Nepal
}

www.ijonse.net

\section{To cite this article:}

Paudel, P. (2021). Online education: Benefits, challenges and strategies during and after COVID-19 in higher education. International Journal on Studies in Education (IJonSE), 3(2), 70-85.

International Journal on Studies in Education (IJonSE) is a peer-reviewed scholarly online journal. This article may be used for research, teaching, and private study purposes. Authors alone are responsible for the contents of their articles. The journal owns the copyright of the articles. The publisher shall not be liable for any loss, actions, claims, proceedings, demand, or costs or damages whatsoever or howsoever caused arising directly or indirectly in connection with or arising out of the use of the research material. All authors are requested to disclose any actual or potential conflict of interest including any financial, personal or other relationships with other people or organizations regarding the submitted work. 


\title{
Online Education: Benefits, Challenges and Strategies During and After COVID-19 in Higher Education
}

\author{
Pitambar Paudel
}

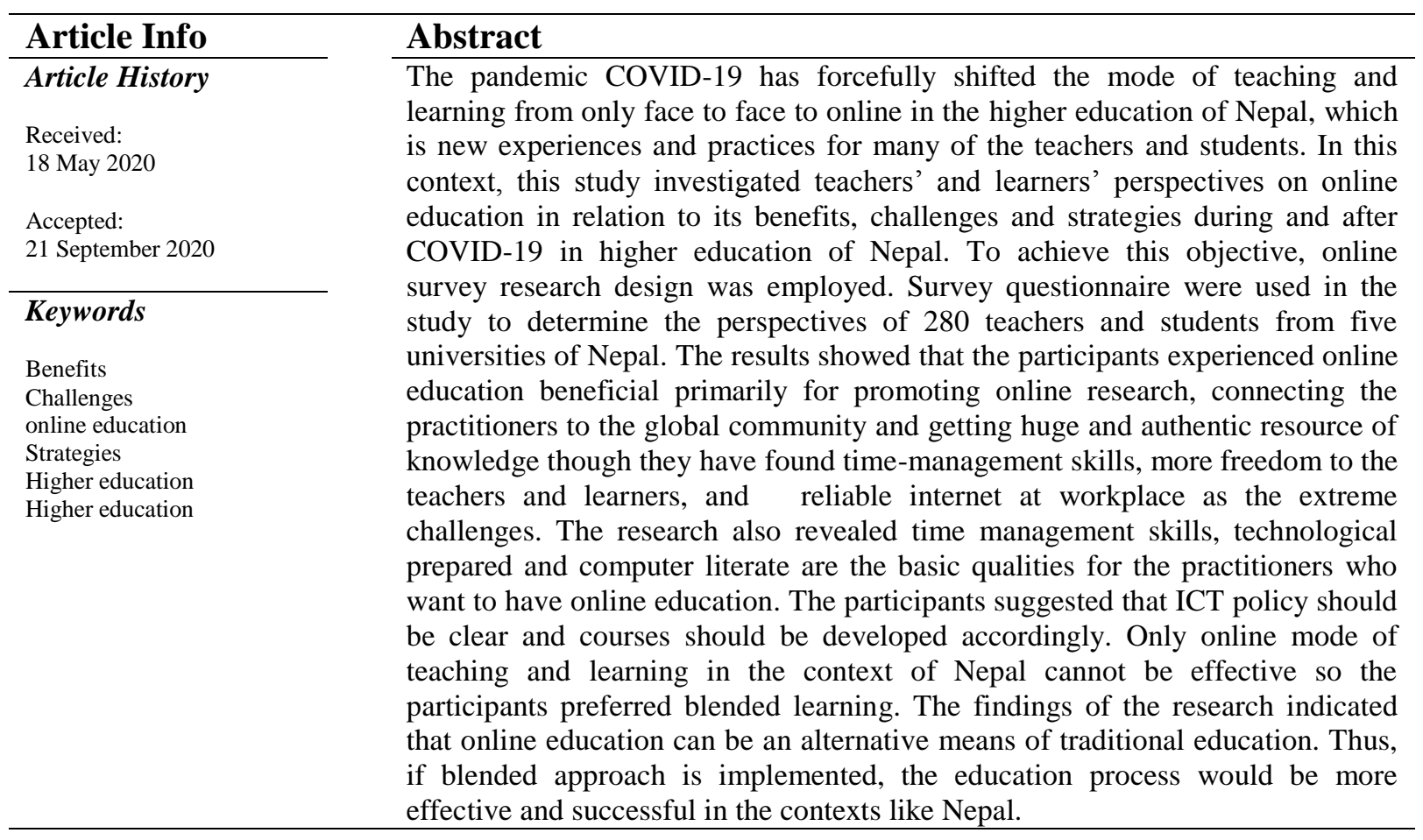

\section{Introduction}

The pandemic spread of Novel Corona Virus (COVID-19) has created fear, anxiety and several concerns among the people around the world. It has disrupted every aspect of human life including education throughout the world. The pace of its spread made educational institution closure as one of the best preventive measure against it. UNO (2020, August) report shows that the COVID-19 pandemic has created the largest disruption of education systems in history, affecting nearly 1.6 billion learners in more than 190 countries and all continents. Closures of schools and other learning spaces have impacted 94 per cent of the world's student population, up to 99 per cent in low and lower-middle income countries around the world. COVID-19 has absconded no segment in whichever country in the planet untouched, and its impacts will be known for years to come. However, when vast impacts were being used to alter and advance elevated education in the world, there is a threat that COVID19 will threaten the segment, with severe penalty.

To mitigate the direct impact of virus and prevent the students from psychological depressed, educational institutions have initiated the momentum of educating the students through different means and modalities based on both human and material resources available in the context. In this context, Anifowoshe et al.(2020) state that the virulent disease has made students to be at home which has led a numerous institutions to organize a variety of e-learning stages (even though with confronts) to assist and make sure that the academic schedule runs to closing stages. Technology based teaching especially online education has become the most appropriate alternative to keep educational activities functional in many parts of the world during the pandemic period. The educational institutions in countries which were technologically advanced like UK, Japan, USA, Turkey etc. promote their technological competencies and those which were technologically poor like educational institutions in Nepal and higher region have initiated using it in teaching and learning process. Showing the obligation of implementing online education in the educational institutions throughout the world Rieley (2020) state that to deal with the two major challenges pertaining with detaining or stopping social contacts and 
keeping learning going, educational institutions in each level of their education have started online teaching $\mathrm{g}$ and learning. Online education has become an effective means to run educational activities functional and prevent the possible loss of academic session created due to lock down in the most parts of world. However, The research on online education shows that students displayed a wide range of responses, with most expressing anxiety toward online learning, disappointment regarding graduation ceremony, and online learning being different than standard in-class learning (Unger \& Meiran, 2020).

In the contrary, the physical brick and mortar of traditional and only face to face classroom has lost its pace and face of teaching and learning with the advent and use of online education, which is taken as a paradigm shift in education brought by COVID-19. Online learning is partially or entirely internet based learning which required both teachers and learners having technological knowledge and skills (U S Department of Education, 2010). In the same context, Pape (2010) states that many researchers and educators are interested in online learning to enhance and improve students' learning outcomes while combating the reduction in resources, particularly in higher education. Online education can take practitioners to a huge resource of knowledge and authentic materials from diverse fields of knowledge and information. Online leaning is believed to be an effective tool in combating the rising cost of postsecondary education by spreading the cost of class over a much to traditional setting of teaching and learning (Tucker, 2007). Online education can be able to provide world knowledge to anyone and anywhere as long as they have access to internet facility. Stern (n. d.) concedes that online courses provide an excellent method of course delivery unbound any time or location allowing for accessibility to instruction at any time anywhere. However, Korkmaz and Toraman's (2020) research reveals that most of the educators experienced some problems during their online learning practices, they expect certain changes in the educational practices in the post-COVID-19 world and they think essential measures must be taken in education against a potential outbreak in the future. Angelova (2020) concedes that online environment make students feel work easier in individual tasks, but not in team works. These accounts exhibit that online can be an effective alternative for physical classroom teaching and learning letting learners' individual autonomy of face and pace of learning at their own place though it has both positive and negative consequences.

Nepal is a small landlocked country situated between two big countries China and India, having geographical, cultural and indigenous diversities. The pandemic spread of COVID-19 has greatly affected all the aspects of the growth and development of the people and country along with economic, political and educational phenomena. The first case of COVID -19 was found in Nepal on January 25, 2020, when a 32 year Nepali student returning from Wuhan, China, was tested positive, Which in the words of Mohydin (2020) was the first phase of virus, where the transmission of the virus was predominantly linked to arrivals from foreign countries. Being a landlocked country, Nepal government should take necessary preventive strategies against the virus because there was a flow in arrival of Nepalese from different foreign countries in one side and the spread of virus in many countries including neighboring countries was massive and quick in the next. But insufficient effort and slow response of the government led the whole country to go lockdown since March 24, 2020 to July 22, 2020. But he COVID cases have been massively increased in the countries. Till September 18, 2020 more than 61000 people are being infected by the virus and more than 390 were killed (The Kathmandu Post, 2020 September 18) and the cases have been increasing in unpredictable manner day by day. As the result of the lockdown in the countries and the unpredictable spread of COVID cases in the countries, schools and universities in Nepal have been closed for nearly five months now. Estimating the effect of COVID-19 on education, UNESCO's (2020) report on May shows that $8,796,624$ students are affected due to school/university closures as preventive measure against the pandemic. Out of this number, 958, $127(11 \%)$ are in pre-primary, 2,466,570 (28\%) are in primary, 3,463,763 (39\%) are in secondary and 404,718 (5\%) are in higher education.

The closure of schools and universities for a considerable period of time has made the institutions and the policy makers including government oblige to plan and implement alternative ways of face to face mode of teaching and learning for keeping educational activities functional. As a consequence, education system has been dramatically changed and shifted into e-learning basically online education in higher education, and teaching and learning through traditional e-learning devices radio and television at school education. Use of fully online based teaching and learning is a new experience for all educators, teachers and learners in Nepali education system. Though Bacos and Grove's (2014) study affirms online education over traditional classes help in promoting quality education and open awareness of more opportunities, there are many challenges around equitable access to e-learning for all the teachers and students in the country. In this connection, Shrestha (2018) raises question on the teachers' confidence, knowledge and motivation in information and communication technology in the context of Nepal. It implies for further research whether the policies of schools and universities of implementing online education for keeping educational activities functional during the pandemic are really implemented. Further, it is important to recognize the benefits of online learning over traditional face to face learning. Moreover, it is also significant to identify obstacles/challenges faced by beneficiaries, and their 
plans or strategies for making this dramatic shift in delivery mode of teaching and learning more effective even after pandemic period. In this rationale, this study is an attempt to investigate benefits, challenges and strategies during and after COVID-19 from teachers' and learners' perspectives specifically in higher education of Nepal.

\section{Review of Literature}

The worldwide spread of COVID-19 pandemic has sent shock waves to the entire higher education system in the world. As the virus spread different forms of lockdowns were put into places and countries across the world. For maintaining physical distancing orders prohibiting larger gatherings face to face learning has moved into online mode within a matter of days in most countries. Students should be provided with feeling secure and keep them engaged in academic activities at their home even if the possibility of face to face meeting and interaction are almost impossible. In this sphere, Lorenzo ( 2008) states that teachers and students interaction, student-to-student interactions and class dialogues in virtual learning environments create an opportunity for students to give and receive emotional support to one another, which is important for student well-being as they dealt with the aftermath of the disaster or any pandemic.

Online teaching and learning becomes effective and successful when teachers and learners engage in meaningful interaction. In this context, Burns and Myhill (2004) concede that learning can be effective when discourse in the classroom is based on discussion between the teacher and students. Interactive learning emphasizes the shift from high level of teachers' control to greater self- centered learning on the students' part. Muijs and Reynolds (2010) force that interaction between teachers and students in a classroom enables the teachers to confirm that the learners understand the principles which have been taught and helps the students to practice and master target language skills and knowledge on the way they think. Using ICT can lead to more positive educational echoes for making interactive language teaching and learning in the classroom. In this context, Cox and Marshall (2007) conclude, "skillful use of ICT by the teachers links to careful pedagogical automation, capacity, range and interactivity" (p. 3) as the basic features of ICT that a language teacher needs to be familiar with. For implementing interactive strategies to enhance classroom communication for getting effective use of ICT in an online classroom, the teacher has to be aware of ICT's range and features as a resource. Similar to this, Somekh and Davis (1999) state that skillful use of ICT by trained practitioners is absolute key to higher attainment. Beauchamp (2012) suggests "speed, automation, capacity, range, provisionality and interactivity" (p. 3) as the basic features of ICT that a teacher needs to be familiar with.

ICT offers a massive capacity for improving the speed of teaching which can be detrimental to the young learners. A language teacher must be conscious and aware of the learners' levels and needs while planning and determining the pace of timing in presenting a lesson (Beauchamp, 2012; Alharbi, 2014). ICT requires a high speed of interactivity between teachers and students, which can be beyond the skill and knowledge of learners so that a good language teacher always brings a balance between ICT pace, learners' abilities and teaching strategies for attaining expected outcome. Moreover, ICT has played an interactive and supportive role in material development and production. In this vein, Alharbi (2014) states that before the advent of ICT, the development of materials in term of scale and creativity was very difficult but ICT reduces such complexities and becomes an integral educational aid for language teachers. Similarly, Beauchamp (2012) mentions that ICTs offer high level of strong capacity, which can make bright future connecting to innovative and creative ELT pedagogies. ICT increases the quality of learning by making access to very high volume of information and knowledge available in the world. Use of ICT gives the learners not only interaction with teachers, but also provides them real life contact with and exposure to the cultures and people of diverse geographies and backgrounds. Ghashemi and Hashemi (2011) argue that providing an opportunity to learn other cultures through comparison with their own is an integral part in language learning and they claim, "Using ICT, particularly email, blogs and video conferencing, facilitate children's interaction and communication with native speakers and other communities by enabling them to use language for real purposes and in real contexts" (p. 309). ICT enhances interactive teaching and learning styles and provides many opportunities for creativity.

ICT tools provide learners with interactive experiences of learning. Describing this fact, Beauchamp and Kennewell (2007) insist that ICT provides a number of advantages, both essential and combined, which contribute to broaden and designate the procedures used inside the classroom. ICT, as an interactive tool, makes learners able to see quick sequences for specific phenomenon and could help in their understanding. As teaching is delineated as a socio-cultural activity and contextualized in the particular setting by the teacher, ICT use enhances teachers' pedagogical beliefs around interactivity that can create suitable strategies to facilitate higher level of attainment. 


\section{Teachers' Influence in Online Education}

The shift of teaching and learning to an online delivery mode obliged by the Pandemic COVID-19, has become an integral part of education system in the world. However, the levels and methods of using them with the aim of achieving quality education are varied and depended upon the various factors associated with Information and Communication Technology (ICT) policy and their practices in education even before the closure of schools and universities as preventive measure against COVID-19 pandemic. In this context, Honey et al.'s (2000) study claims that in order to achieve positive results in incorporation of teaching technology, it is necessary to understand the types of interaction among the teachers, students and technologies. The use of ICT has brought a paradigm shift in the relationship between teachers and students. In order to integrated ICTS in classroom teaching and learning successfully and effectively, teachers' perspectives on teaching, their ICT knowledge and skills, and their teaching methodologies paly an influential role. In this backdrop, Erstad (2010b) from his study in Norway emphasizes on the role of teacher as being more advisor, critical dialogue partner of the students and leader for specific subject domains. This means to state that teacher is promoting greater independence of learning. Teachers use ICT to change the way that they interact with the students. In this vein, Scardamalia (2002) states that the teachers' role in using ICT in language teaching should be for promoting learning outcomes of the learners. In this sense, teachers use ICT to enhance their personal work, professional development and for developing and creating new strategies, thinking, reflecting on practice and engaging the students in several meaningful activities and tasks for better learning outcomes.

Teachers are the keys to transfer the teacher centred approach into learner friendly learning through technology based teaching. Duraku and Hoxha (2020) state that teachers' perspectives on teaching methodology has been proven to influence the level of technology integration in the classroom and are also expected to play significant role on successful implementation of online learning. Online teaching and learning should try to support the learners' needs and expectation rather than delivering the subject matter only from teachers' perspective even if the courses are not ICT friendly and are not designed in such a way in the context of Nepal.

Moreover, Palmer et al.(2009) suggest security, level of self-satisfaction, the time and dedication of both teachers and students needed to implement the changes as the major factors that determine the quality of online education( as cited in Ibrahim et al., 2013). Changes in education system occurred due to either as the preventive strategies against pandemic COVID or implemented as a part of regular educational improvement may not be easily accepted by the concerned stakeholders in the sense that such changes may create something unusual than that of normal or regular practiced. In this vein, Ibrahim et al. (2013) concede that changes in the educational patterns may create resistant among or within the group of people who lack interest in change and wish to maintain their usual status quo. Moreover, institution, institutions" culture and their policy and support both for teachers and students are also key factors that determine the quality of online or distance education ( Per \& Kitson, 2014). Online education may have only good aspects but it may have drawbacks according to the context and course. Hebebci, Bertiz, \& Alan (2020) find that teachers and students had both positive and negative attitudes towards distance education whereas Serhan ( 2020) finds that students had a negative attitude toward the use of Zoom.

All these literatures imply that the success of online education and change in educational management system depend upon teachers' dedication, motivation, time, support and technological knowledge and skills.

\section{ICT Policies and practices in Nepal}

The education system of Nepal consists of four overall levels: pre-primary (up to 4 years of age), basic education ( 5 years to 12 years of the age and grade 1 to 8 ), secondary education (13 to 17 years of age and grade 9 to 12) and higher education (18 to above of the age and Bachelors to Ph.D. levels) (ADB, 2015). In addition, there is also the provision of a separate technical education of one and half years to three years (TSLC and Diploma) (MOE, 2013). The overall school education system of Nepal is guided, governed, managed and implemented by the ministry of education (MOE) whereas universities are governed and managed by the respective university acts.

Online education is a new phenomenon in Nepal science the ICT education policy has been introduced in the last two decades. The IT policy of 2000 introduced information technology for the first time in Nepal and was revised in 2010 with the provision of expanding the access of internet to all schools with collaboration and coordination of both governmental and non-governmental organizations so that skilled human resources can be produced for quality and relevant education (Joshi, 2017; Karki, 2019). With the implementation of secondary 
sector reform plan [SSRP] (2009-2015), ICT associated teaching/learning strategies in all schools were expanded and Department of Education (DOE) provided 140,000 amount for each secondary school for purchasing 3 computer and a printer, and at the same time, some schools were supported with computers by some non-governmental organizations (MOE, 2009). The three year plan (2011-13) focuses on encouragement of ICT use in school education with the goals of increasing access to relevant and quality education in rural areas, to reduce digital divide and integration of ICT in all aspects of education (Joshi, 2017). It was the first government strategy to encourage ICT in education basically at school education level. The first ICT education policy was ICT master plan (2013-2017) which aims to equal and equitable access for enhancing quality education by improving service delivery system and increasing digital device in education (MOE, 2013). The development and integration of ICT in education system, e-learning, ICT based teacher training, use of computer technology in classroom teaching and learning process, electronic based distance education and teacher training using ICT were highly prioritized in the national ICT policy 2015 (Joshi, 2017). ICT has been made not only a tool of teaching but also a part of teachers' professional growth and development.

The School Sector Development Plan [SSDP] (2016-2023) presents ICT as an integral part of school education where each subject curriculum is supposed to have been supported with ICT. More specifically, SSDP (20162023) focuses on (i) the adequate use of ICT to improve pedagogical practices like classroom delivery, increasing interaction, (ii) development of skilled human resources; instructional materials, (iii) integrating and incorporating ICT in the secondary curriculum through professional development guidelines and packages, (iv) the use of ICT for improvement and enhancement of overall educational governance and management effectively and efficiently, and (v) prepare ICT teaching and training materials both online and offline focusing on English, science and maths (MOE, 2016). This policy intends to implement ICT in school to full extent for developing relevance skill and quality of education.

As per the policy of the government, the academic institutions have begun online education in their practices. As a part of promoting online education to facilitate face to face mode, and providing access to quality higher education to mass people through open and distance learning mode, Tribhuvan University established Open and Distance Education Centre in 2015 with the aim of the aim of providing access to quality higher education through open and distance learning mode for the students who cannot attend the regular class (TUODEC, 2015) though very few students got enrolment in this program.

The COVID -19 pandemic urges the university to implement online education in its all the faculties and departments. As a result, Tribhuvan University has declared implementing online education as preventive measure of academic loss. It has introduced online classes guideline, provided it domain email account for the teachers and students, and also trained both teachers and students in using MS Team as an official software for teaching, learning, emailing and doing any tasks related to the university ( TU,2020). Similarly, Nepal Open University which used to have online mode of teaching and learning even before the pandemic promoted its technological competencies and running its regular programme. Other universities like Kathmandu University, Pokhara University, Mid- Western University, Far-Western University and almost all the schools and colleges have been practicing online teaching and learning to keep and run educational activities functional and not to make possible academic loss created by the closure as preventive measures against COVID-19. In this context, the present study is an attempt to investigate the effect of online education in terms of its benefits from teachers' and students' perspectives in higher education of Nepal. Moreover, it also tries to explore their suggestions as the possible strategies to be adopted during and even after the pandemic COVID-19 for making online mode of teaching and learning more effective and successful as a paradigm shift in the deliver mode of education system of higher education in Nepal.

\section{Theoretical Stand of the Study}

This study employed constructivist approach as its theoretical framework to explore the teachers' and students' perspectives on online education in terms of its benefits, challenges and the possible strategies to be adopted during and after the pandemic COVID-19 in the higher education of Nepal. Online education is to be interactive enough for effective and successful teaching and learning. Lou (2005) notes that the rapid growth and development of ICTs in teaching and learning has given birth to several methods like problem based learning, interactivity, case based learning, task based learning that are based on constructivist theory. Constructivist theory based methodologies and approaches are more student centered, promote group works, pair works and project works that can promote communicative ability, and they are process based focusing on inferring meaning, forming opinions and developing critical thoughts. 


\section{Methodology}

This study aims to investigate teachers' and students' perspectives on benefits and challenges in teaching and learning through online mode of delivery shifting from traditional face to face mode during and even after the pandemic COVID-19 in higher education of Nepal. Moreover, this study intends to get suggestions from both the practitioners to be adopted as possible strategies in online education of Nepal. For achieving the objectives, online survey under quantitative inquiry was employed. Online survey is a set of structured and unstructured questions on a particular issue that the respondents complete over the internet, generally filling out a form (Bhat, 2019). It is a natural way of reaching out to the respondents consuming less time. The study employed both the primary and secondary sources of data because only one type of data alone could not fulfill the total requirement of the research. The primary data were collected by using online survey questionnaire to teachers and students from higher education of Nepal, who have been engaging in online education during pandemic period. The secondary data were collected from references, textbooks, journals, and other archive resources. The data and methodology have been triangulated to ensure validity and reliability of the findings.

Involving all teachers and students in this study was not possible due to constraints like time and scope of the study. In this context, it was essential to ensure that the study is representative. Thus, 150 teachers and 150 students from five universities of Nepal ; Tribhuvan University, Kathmandu University, Mid-western University and Far-western University and Pokhara University of Nepal were randomly selected as sample of the study. The selected participants were sent survey questionnaire (Appendix A) that includes both closed and open ended questions prepared in Google form through email and sending link in Facebook messenger. However, only 280 participants responded the questions. Thus the actual sample size of the study was 280 that include 160 teachers and 120 students. The data in this research is gathered and stored in database Google form, which the researcher evaluated and analyzed after receiving responses from all the respondents. After all the responses were collected, the data was analyzed using simple statistical tool percentage followed by a descriptive analysis, and then the results were interpreted in the discussion.

\section{Results}

Since the present study was an online survey aimed to investigate teachers' and learners' perception to online education in term of benefits, challenges and strategies during and after pandemic COVID in the higher education of Nepal, the data were collected through three sets of closed ended questionnaire and one set of open ended questionnaire. Thus, the analysis and interpretation was made on the four parameters based on the questionnaire.

\section{Participants' Preferences on Online Education}

With the aim of examining the benefits of online education in higher education of Nepal, the participants were asked a question with fifteen alternatives in which they were allowed to choose more than one items. Figure 1 presents the participants' responses towards benefits of online education at higher education of Nepal. Figure 1 demonstrates that online mode of education was believed to be beneficial to promote online research and resources as reported by $84.6 \%$ of the informants, and connect people to global village as reported by $84.4 \%$.

Similarly, $76.9 \%$ of the informants expressed that online courses increase independency in learning. Likewise, online education was helpful for the learners to work in their own pace and make them self-disciplined as expressed by $69.2 \%$. Further, the results exhibit that the equal number of the participants ( $61.5 \%)$ believed that online courses provide flexibility in their modes and modalities, provide huge resource of knowledge, participants can learn the knowledge of the at their home and they provide updated and authentic information.

Moreover, the results in Figure 1 show that $46.2 \%$ of the participants expressed that online course are advantageous for them because they are more convenient, offer individual attention towards learning and promote lifelong learning. Only few participants believed that online courses did have financial benefits (38.5\%), help to meet interesting people (30.8\%) and provide them real world skills. The results show that large number of participants found online learning beneficial even if it was their first experience having fully online courses teaching and learning situation created due to pandemic COVID-19. 


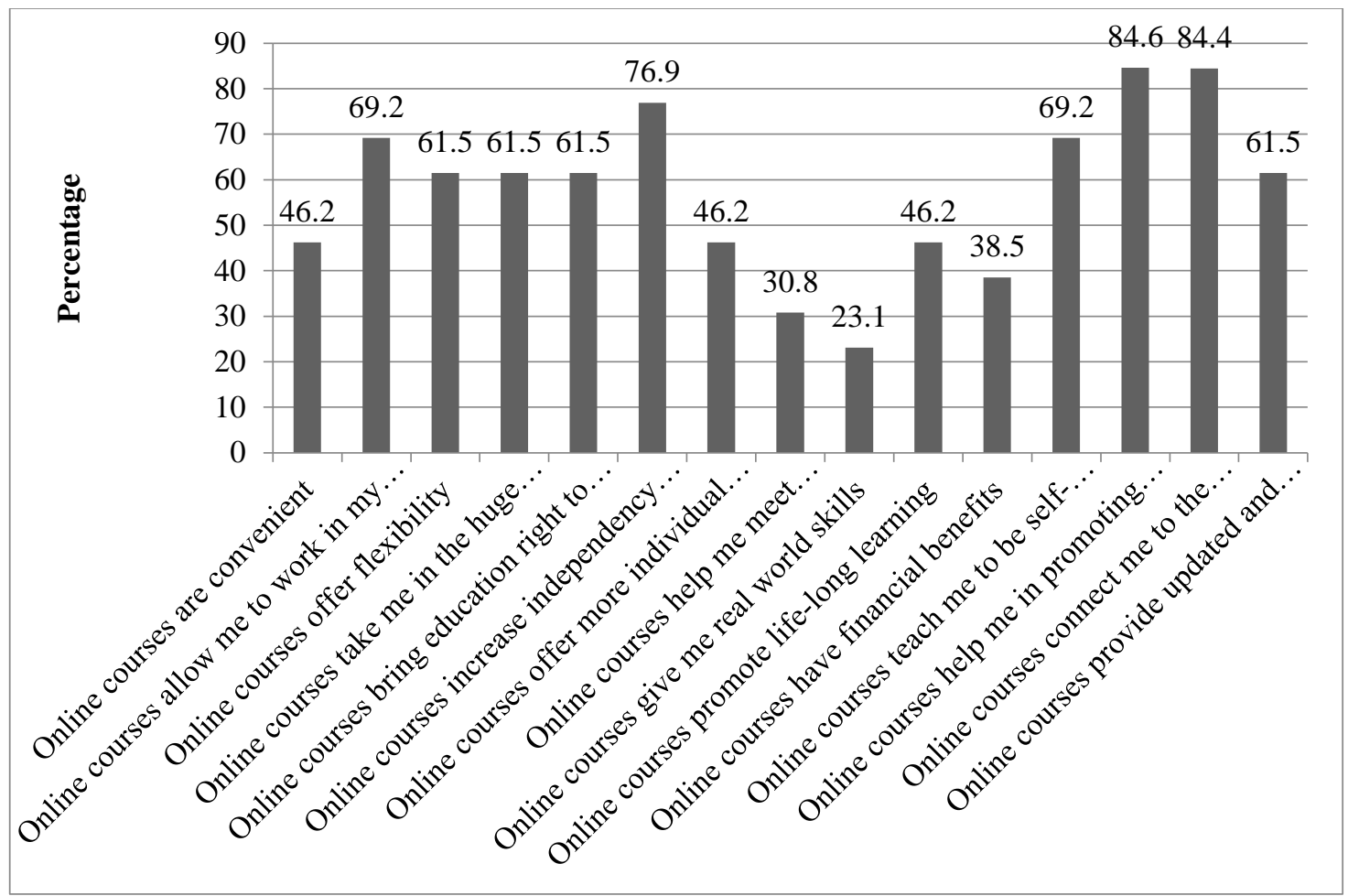

Figure 1. Participants’ Perspectives on Benefits of Online Education

\section{Faced Challenges in Online Education}

This set of questionnaire included one question consisting fifteen alternatives where the participants were free to choose more than one options to determine the participants experience towards the challenges that they have been facing in online teaching and learning. Figure 2 presents the participants' experiences towards the challenges in teaching and learning online courses at higher education of Nepal.

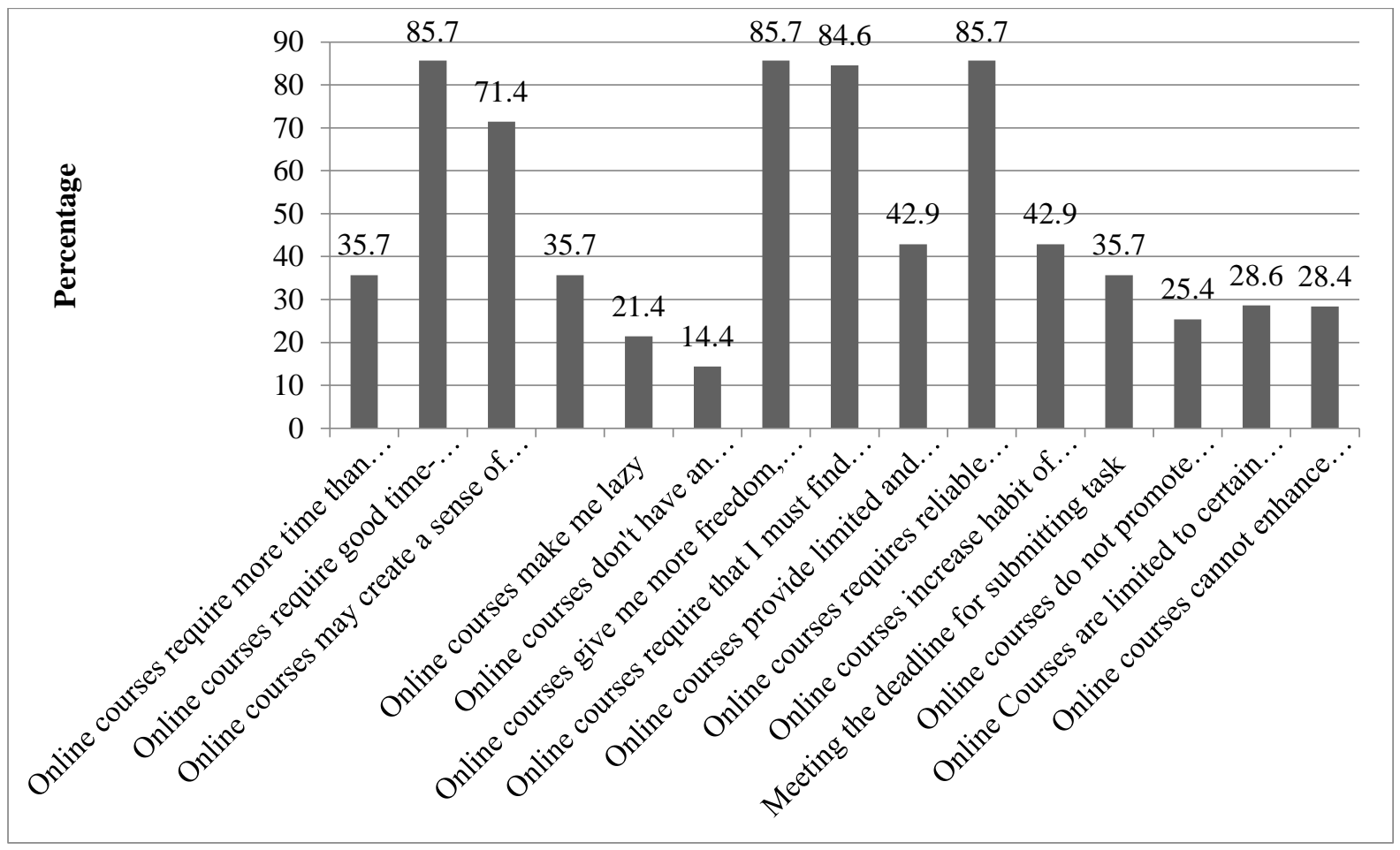

Figure 2. Challenges Faced on Online Learning 
Figure 2 displays that time-management skills, more freedom to the teachers and learners, and reliable internet at home are the extreme challenges that majority of the participants (i.e.85.7\%) experienced in online courses. Similarly, finding the path of own learning by the learners was taken as the challenge in online teaching and learning by $84.6 \%$ of the participants while $71.4 \%$ felt creation of social isolation as the challenge. Less than half percentage of the participants realized limited and delayed feedback (42.9\%), create habit of plagiarism/cheating (42.9\%), intend learners to be independent to the resources $(35.7 \%)$, and meeting the deadline for submitting the tasks $(35.7 \%)$ as the challenges in online courses.

Moreover, less than thirty percentage of the participants experienced that online courses make them lazy $(21.4 \%)$, online courses do not promote practice-based learning (25.4\%), online Courses are limited to certain discipline $(28.6 \%)$, and online courses cannot enhance accreditation and quality in learning $(28.4 \%)$. Very few participants ( i.e. 14.4\%) took that online courses don't have an instructor hounding them to stay on task. The results exhibit that time management for online courses, access of reliable internet service and more freedom given to the participants are the accelerating challenges in online teaching and learning while instructor hounding them to stay on tasks is the less challengeable parameter in online courses.

\section{Participants' Qualities Required for Online Education}

With the aim of exploring the characteristics required for effective online teaching and learning from teachers' and learners' perspectives, who have been practicing online courses, the participants were asked a question with ten alternatives allowing them to choose more than one alternatives. Figure 3 presents the participants' responses towards the required characteristics on participants for online education at higher education of Nepal.

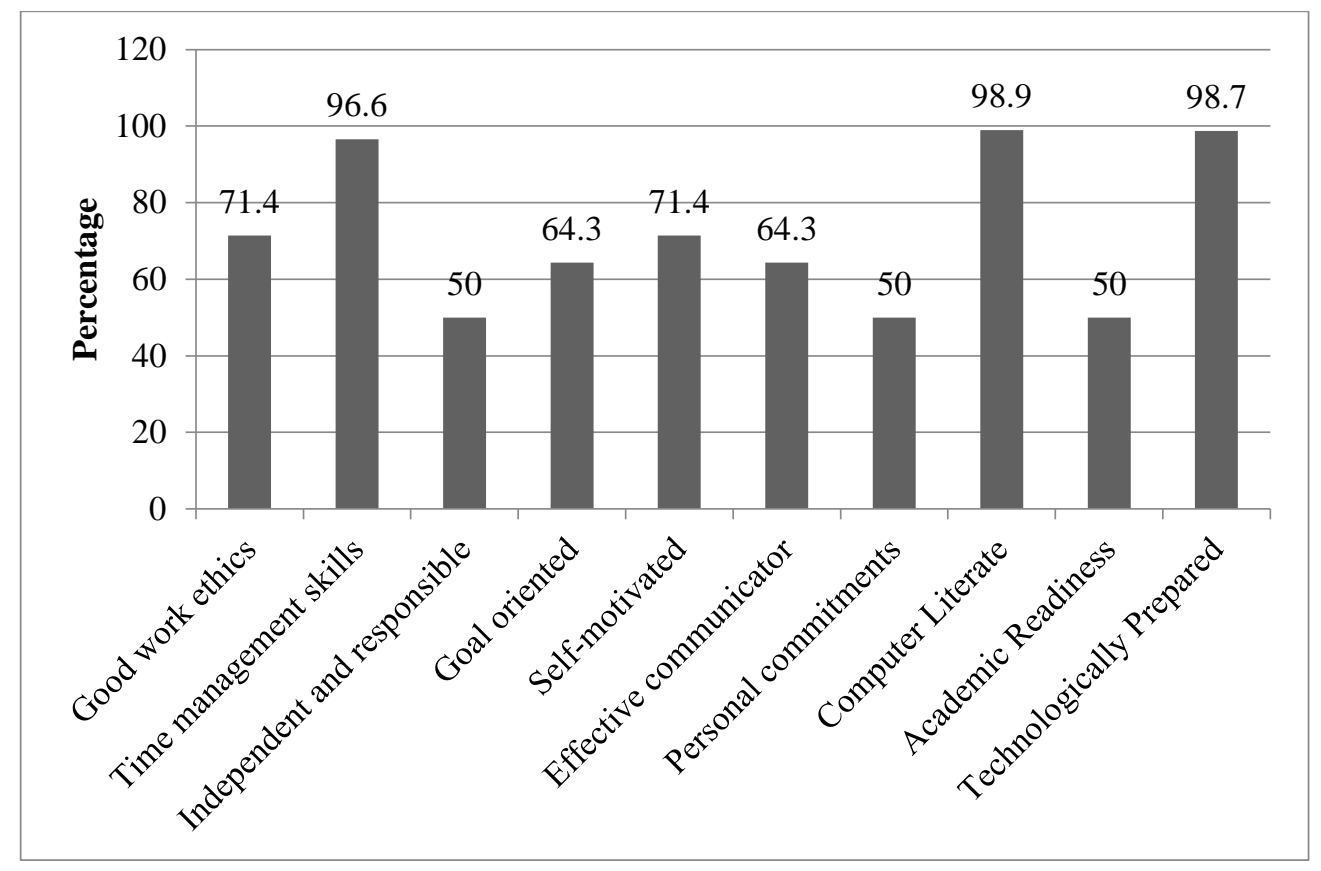

Figure 3. Qualities Required for Online Education

Figure 3 exhibits that almost all the participants (i.e. 98.9\%) participants realized that computer literate is the mostly required characteristic for the learners who have been engaging or want to engage in online education and about equal percentage $(98.7 \%)$ of the participants expressed technologically prepared as the required characteristics while $96.6 \%$ of the participants believed time management skill as the quality required for online education. Similarly, more than half of the participants felt that good work ethics (71.4\%), self- motivated $(71.4 \%)$, effective communicator $(64.3 \%)$, and goal oriented $(64.3 \%)$ are the features required in an individual for effective online education. Only half of the informants (i.e. 50\%) expressed that independent and responsible, personal commitments and academic readiness are the qualities required for online course teachers and learners. The results exhibit that computer literate, technological preparedness and time management skill are the most required characteristics on an individual for effective and successful online education. 


\section{Future Strategies and Recommendations}

With the aim of finding out the participants viewpoints on their future strategies and the recommendation for effective online education, they were asked five open ended questions. In response to the first question whether they would like to take more online courses in the future, all the participants (i.e.100\%) responded that they are eager and ready to take online courses in future but the reasons behind this phenomenon are different. Around $60 \%$ of the participants wanted to remain up to date with new information, get authentic information and resources through online courses. Similarly, 55\% of the participants reported that they wished to have more online courses because they found them flexible in terms of time and place, provide opportunities of sharpening themselves professionally and they wanted lifelong learning through online education. One of the participants wrote, "I want to educate through online mode because it provides me more opportunities of getting new knowledge, skills and change my attitude and professional capability". Around 30\% of the participants thought them as techno friendly and want to learn and teach online courses as they believed online education is the cry of the day.

Concerning to the second question under the parameters about the suitable age for online education $75 \%$ of the participants believed that online education can be effective for the learners who are above 16 years of age. However, $20 \%$ of then expressed that the suitable age for online education is the age of higher education which in the context of Nepal is tentatively 18 years. Very few of the participants (i.e. 1.5\%) wrote that the learners above the age of 7 years can be engaged in online education, and $3.5 \%$ of the respondents did not reply this question. The results exhibits that majority of the participants are infavour of online education in higher education rather than school education.

Similarly, the third question intended to explore the participants' advice to the instructors/ students who are planning on setting up and instructing an online course, all the participants (100\%) advised more than one suggestions. The common advises that all the respondents expressed were that online courses should focus on need and interest of both the instructors and learners and the participants should be well prepared and always seek result, sensitive on the course that is assessable to most, self e-disciplined encouraging themselves, punctual and try to be inclusive and mostly should be capable for time management and they should be digitally literate. One of the informants stated, "Start simply and do not hurried in panic, repeat the content to be taught and learned time and again and manage time and access well". In the same issue, $60 \%$ of the participants suggested that both the instructors and learners should have self- learning motivation; cooperation with each other's and should follow ethics of technology. Likewise, $56 \%$ of the participants reported that online teaching should not be the replication of traditional teacher centered lecture method rather more focus should be paved to engage individual learners as per their abilities.

In response to the question what suggestions the participants would like to provide to the policy makers, course designers regarding online education practices in education of Nepal, all the respondents responded that in the context of Nepal, the curricula and course should be ICT friendly which are not at present time even though the practices of online teaching learning have been taking place due to the situation created by the closure as preventive measure of COVID-19. Similarly, all the respondents agreed that only online education cannot be effective in the context of Nepal, rather they suggested the policy maker to encourage the blended mode of learning incorporation face to face and online modes in proper manner. Similarly, in the same issue, $71 \%$ of the participants advised that ICT policy should be clearly framed and its implementation should be made effective. Moreover, $60 \%$ of the respondents urged the government to make internet service accessible to all the learners throughout the country for making online education possible otherwise, traditional mode of teaching and learning cannot be replaced. All the respondents (i.e. 100\%) reported that before implementing ICT in educational institutions, digital contents of all levels should be easily available where every institution should have good ICT infrastructures. All of them suggested that online education can be an alternative means but cannot and should not replace face to face mode of learning. Online courses need to be carefully designed considering the limitations and opportunities of virtual space for learning. This is not forceful practice of delivering traditional courses through online mode. Likewise, in response to the fifth question whether online education needs integration of face-to-face interaction for more effective implementation and results in the context of Nepal, all the respondents had the same opinion that without an online education should go along with face to face interaction. If they go side by side, teaching learning will be more lively and effective during the time of pandemic COVID-19 and even after it. Online education has become a growing phenomenon throughout the world but when it is integrated with face to face mode it can compensate the loop holes fond in face to face and online education. 


\section{Discussion}

The social isolation and the creation of new circumstances against the spread of COVID-19 have brought a forceful shift in the education of Nepal especially in delivery mode though COVID has caused fear, anxiety and stress among the people around the world. The only face to face mode of traditional classroom teaching and learning has been turned into online which has become a new experiences and practices for many teachers and learners in the higher education of Nepal. The present study examined the teachers' and learners' perspectives on online education in terms of its benefits, challenges and strategies during and after COVID-19 in higher education of Nepal. The results in the first issue on the benefits of online education indicate that more than $70 \%$ of the participants found online courses beneficial for promoting online research, connecting the practitioners to the global community and getting huge resource of knowledge. This finding corroborates with Sun and Chen's (2013) claim that online education provides potential opportunities to open up new markets for higher education institutions, and Finch and Jacobs (2012) who stated that online education reduces the time and costs for travel increases opportunities to access and collaborates with expert professionals in a global range. Similarly, more than $50 \%$ of the participants expressed that online courses are beneficial for them because they provide them flexibility in terms of time and space of teaching and learning, provide them authentic and huge resources of materials required for professional and academic endeavor, and make them self -disciplined which reveal what and Finch and Jacobs (2012) argue that online education can be advantageous by providing students and teachers with flexibility to access courses at their convenience; and allowing adjustments to subjects and content need. The Online learning in this sense meets the needs of an ever-growing population of students who cannot or prefer not to participate in traditional classroom settings. Many adult learners may enjoy the flexibility when they have to balance work, study, and family responsibilities. The wide range of various technology advancement used by universities' online programs may enhance the interaction between students and instructors, and among students at large (Bell \& Fedeman, 2013). Moreover, the nature of the anonymity in the online environment may allow more students, those who cannot attend face-to-face classes because of their personal obligation, to participate in online education where they do not physically see each other. Finally, the upgraded technology and software may allow instructors, students, and university administrators to collect data, feedback, and evaluation regarding their online experiences.

Concerning the second issue that the challenges the participants have faced in online education, the results show that time management skill, reliable internet connection at workplace, learners autonomy of finding the path of learning themselves and more freedom to the learners in terms of time and space are the major challenges for more than $80 \%$ of the participants. Similar to this finding, Kebritchi et al. (2017) also claim that time management is the great issue in online education. Bhusal and Rimal (2020) claim that many of the teachers and students in higher education of Nepal are not in proper internet connection which validates the finding of the present study. This findings also assimilates with Akyıldı's (2020) research findings where he finds that lack of interaction, and communication which lead the students to isolation, problems about exams, traditional educational habits, the load of assignments, and time management are the challenges faced by the students in online mode of education. Similarly, more than $70 \%$ of the participants felt that online classes created social isolation which contrasts with Duraku and Hoxha (2020) who claim that the development of the online learning process positively affects citizens by providing support to more easily overcome the isolation period. If developed based on factors that can improve the quality of education, this implementation can have positive long-term effects, as highlighted by previous studies that argue that student well-being is affected by the quality of learning (Gjoshi \& Kumi 2014). Likewise, delayed feedback, case of plagiarism as challenges were taken by less than half or the participants and few of the participants took lack of instructor hounding, online courses limited to particular discipline and the case of quality and accreditation as the challenges in online education.

The third issue investigated in the study concerns with the characteristics of the participants required for online education where majority of the participants expressed that time management skills, technological prepared and computer literate as the basic qualities for the practitioners who want to have online education. Similarly, more than $60 \%$ of the participants realized good work ethics, effective communicators and goal oriented learning as the qualities while half of the participants felt academic readiness, personal commitment and independent and responsibility are the qualities required for effective online teaching and learning. These findings indicate an ideal online education uses computer tutorials and online learning activities, simulation and manipulative in an interactive way; uses the dimensions of online learning to create positive attitudes in learners and supports different types of learning experiences (Meylani et al. 2015). Likewise, Gilbert (2015) states that it is important for potential online learners to understand the differences between a traditional classroom setting and an online classroom setting, since there are benefits and drawbacks to both environments that can possibly affect their overall performance as a student. 
The eagerness of the participants for getting more online courses indicates the need and value of online education to bring shift in the traditional classroom teaching and learning. Online learning appeals to diverse populations of the practitioners with ranging academic needs that traditional education classes are deficient or incapable of meeting the needs and demands of the postmodern learners in the context of Nepal. The demand for online courses is derived from a push "to provide quality education to all students, regardless of location and time" (Chaney, 2010, p.21). Online education is taken as the hope of authentic resources and global communication. The participants views on the suitable age for inline courses are varied which indicate more research on the issue and make appropriate online education policy in the context of Nepal even after COVID19 to implement online education effectively. The results further reveal that the participants suggested that online courses should be need, interest and level based, result oriented and should encourage self- motivation and cooperation among the learners. The results further signify that participants suggested implementing blended learning in the context of Nepal because face to face and online modes of learning affirmative, interactive and complement to each other, where face to face mode makes access to peers and experts and online mode has access to huge resources. This finding of the study assimilates Kaur's (2013) claim that face to face learning serve to cater the learners with certain learning preferences while online learning can give a higher degree of learning autonomy. Moreover, the results point out that the policy makers should make clear and adequate ICT policy for making effective online education as an alternative means of traditional mode of teaching and learning. Clear ICT policy is a crucial element of academic computing (Mokhtar \& Alias, 2006). Specific ICT policy in education helps the institutions and teachers and learners to manage their ICT facilities, resources and ICT protection and enhance their quality in online education. The growing number of online courses and programs creates a need for more research in this particular area. More research would open doors to making students more aware of the benefits and potential drawbacks of online coursework as well as characteristics of a successful online student. Instructors and course designers should understand effective course development and design so students have a heightened chance for success.

\section{Conclusion and Implications}

This study tried to investigate teachers', and learners' perspectives on online education in terms of benefits, challenges and strategies during and after the pandemic COVID-19 in higher education of Nepal. The research revealed that the participants found online education beneficial though it was their first experiences of having only online courses. They found that online education is highly beneficial promoting online research, connecting the practitioners to the global community, getting huge and authentic resources of knowledge required for professional and academic endeavor, and make them self -disciplined.

As to the shift of traditional mode of teaching and learning due to closure as preventive measure of pandemic COVID19 into online education, the participants experienced time management skill, reliable internet connection at workplace, learners' autonomy of finding the path of learning themselves and more freedom to the learners in terms of time and space, creation of social isolation, delayed feedback, case of plagiarism as the great challenges. Online education and its success lie in the participants and their qualities. The research reveals that time management skills, technological prepared and computer literate, good work ethics, effective communicators and goal oriented learning, academic readiness, personal commitment and independent and responsibility are the major characteristics for the practitioners who want to have online courses.

The research also reveals the participants' eagerness towards online courses since it provides updated and authentic materials which they can learn in their own way. However, their doubt in the age for online learning creates the avenues for more research regarding the mode and modalities of online education in the context of Nepal. The participants suggest that online courses should be as per the needs, levels and interest of the practitioners. This implies that the courses practiced currently are not ICT friendly so the policy makers should make appropriate ICT policy and course designers have to design ICT friendly curricula and courses, which can make online education more effective and result oriented.

The participants suggested online education as an alternative means and blended learning could be better in the context of Nepal where there is no reliable internet connection in workplaces and the teachers and students are not fully techno friends. This implies blended learning can play a vital role in higher educational context of Nepal if its implementation is made adequate to the learners' needs, levels, interests, and contexts addressing both cognitive and affective domains of learners. At the same time, the universities should take appropriate strategies to make the policy, classroom, curricula, teachers and students blended learning friendly so that the balance between online education and face to face mode of teaching and learning. 
Though this study yielded a number of statistically significant results, some caution must be taken in the interpretation and generalization of the results. In fact, online learning can be differing from context to context in terms of particular technological and pedagogical strategies and phenomena. The next limit of this study is that it only reflected teachers' and learners' perspectives on online education, which does not indicate learners' performance in the corresponding areas. The finding of the succeeding research would be more revealing if learners' performance has been taken into account. Nonetheless, it is believed that the present study has brought wave of research in online education and the related phenomena in the context of Nepal. Moreover, it provides feed back to the teachers and students to bear desirable qualities for online education and for the policy makers, curriculum designers and textbook writers to develop appropriate ICT policy, and ICT friendly curricula and courses suitable in the context of Nepal even after the fear of pandemic COVID-19.

\section{References}

Alharbi, E. (2014). A study on the use of ICT in teaching in secondary schools in Kuwait(unpublished Ph. D. dissertation). Cardiff Metropolitan University, Kuwait.

Angelova, M. (2020). Students' attitudes to the online university course of management in the context of COVID-19. International Journal of Technology in Education and Science (IJTES), 4(4), 283-292.

Anifowoshe, O., Aborode, A. T. , Ayodele, T. I. , Iretiayo A. R., \& David , O. O. (2020). Impact of COVID-19 on education in sub-saharan Africa. Paperprint (www.preprints.org). doi:10.20944/preprints202007.0027.v1

Bacos, C., \& Grove, K. (2019).Using online education to improve traditional classroom instruction: A blended learning approach. Society for Information Technology \& Teacher Education International Conference (pp. 374-379). Association for the Advancement of Computing in Education (AACE).

Beauchamp, G. (2012). ICT in the primary school in pedagogy to practice. London: Pearson

Bell, B. S., \& Fedeman, J. E. (2013). E-learning in postsecondary education. The Future of Children, 23(1), 165-185.

Bhat, A. (2019). What is survey: Definition, templates, methods, characteristics and examples. Question.com/blog/surveys

Bhusal, S., \& Rimal, S. (2020). Challenges of Online Learning in Nepal. https://www.researchgate.net/publication/341930135

Burns, C., \& Myhill, D. (2004).Interactive or inactive? A consideration of the nature of interaction in whole class teaching. Cambridge Journal of Education, 34(1), 35-49.

Chaney, E. G. (2010). Web-based instruction in a rural high school: A collaborative inquiry into its effectiveness and desirability. NASSP Bulletin, 85 (628), 20-35.

Cox, M. J., \& Marshall, G. (2007). Effects of ICT: Do you know what we should know? Education and Information Technologies, 12(2), 59-70.

Duraku, Z. H. , \& Hoxha , L. (2020).The impact of COVID-19 on education and on the well-being of teachers ,parents, and students: Challenges related to remote (online) learning and opportunities for advancing the qua... https://www.researchgate.net/publication/341297812

Erstad, O. (2010b). Educating the digital generation: Exploring media literacy for the $21^{\text {st }}$ century. Nordic Journal of Digital Literacy, 5(1), 56-71.

Finch, D., \& Jacobs, K. (2012). Online education: Best practices to promote learning. Proceedings of the Human Factors and Ergonomics 56th Annual Meeting. https://doi.org/10.1177/1071181312561114

Ghashemi, B., \& Hashemi, M. (2011).ICT: New wave in English language learning/teaching. Procedia Social and Behaviour Sciences, 15, 3098-3102.

Gilbert, B. (2015). Online learning revealing the benefits and challenges. https://fisherpub.sjfc.edu/cgi/viewcontent.cgi?article=1304\&context=education_ETD_masters

Gjoshi, R., \& Kume, K. (2014). Research on the administrator professional training and its role in the implementation of educational institutions reforms in Kosovo. Interdisciplinary Journal of Research and Development, 1, 26-30

Hebebci, M. T., Bertiz, Y., \& Alan, S. (2020). Investigation of views of students and teachers on distance education practices during the Coronavirus (COVID-19) Pandemic. International Journal of Technology in Education and Science (IJTES), 4(4), 267-282.

Honey, M., Culp, K. M., \& Carrigg, F. (2000). Perspectives on technology and education research: Lessons from the past and present. Journal of Educational Computing Research, 23 (1), 5-14.

Ibrahim, A., Al-Kaabi, A., \& El-Zaatari, W. (2013). Teacher resistance to educational change in the United Arab Emirates. International Journal of Research Studies in Education, 2(3), 25-36.

Joshi, D. R. (2017).Policies, practices and barriers of ICT utilization in school education in Nepal. International Journal of Research in Social Sciences, 7(2), 468-417. 
Karki, H. (2019). A brief history of public education, information and communication technology (ICT) and ICT in public education in Nepal. Deerwalk Journal of Computer Science Information Technology, 24, 78-103.

https://www.researchgate.net/publication/332698627_A_Brief_History_Of_Public_Education_ICT_and_ ICT_In_Public_Education_In_Nepal

Kaur, M. (2013). Blended learning, its challenges and future. Social and Behavioural Sciences,93 (2), $612-617$.

Kebritchi, M. , Lipschuetz, A. , \& Santiague, L. (2017). Issues and challenges for teaching successful online courses in higher education: A literature review. Journal of Educational Technology Systems, 46 (1), 429. Doi: $10.1177 / / 0047239516661713$

Kennewell, S., Beauchamp, G. (2007).The teachers of interactive whiteboards and their influence on learning. Learning, Media and Technology, 32(3), 227-241.

Korkmaz, G. \& Toraman, Ç. (2020). Are we ready for the post-COVID-19 educational practice? An investigation into what educators think as to online learning. International Journal of Technology in Education and Science (IJTES), 4(4), 293-309.

Lorenzo, G. (2008). The Sloan semester. Journal of Asynchronous Learning Networks, 12(2), 5-40. https://files.eric.ed.gov/fulltext/EJ837474.pdf

Lou, W. (2008).Cultivating the capacity for reflective practice: A professional development case study of L2/EFL teachers (unpublished Ph.D. dissertation).Kent State University, Kent, OH.

Meylani, R. , Bitter, G., \& Legacy, J. (2015). Desirable characteristics of an ideal online learning environment. Journal of Educational and Social Research, 5(1), 203-216. Doi:10.5901/jesr.2015.v5n1p203

MOE (2009).School sector reform plan. Ministry of Education, Government of Nepal.

MOE (2013).ICT in education: Master plan, 2013-2017. Government of Nepal, Ministry of Education.

MOE (2016).School sector development plan 2016/2017-2022/23. Government of Nepal, Ministry of Education.

Mohydin, R. (2020). The coronavirus pandemic in South Asia: Challenges and responses. TRT World Press. file:///C:/Users/rashish/Downloads/The_Coronavirus_Pandemic_in_South_Asia_C\%20(1).pdf

Mokhtar, S., \& Alias, R. (2006).Rubric for assessing ICT vision, plan, policies and standards in Malaysian higher education (post graduate annual research seminar). University of Technology, Malaysia.

Muijs, D., \& Reynold, D. (2010).Effective teaching: Evidence and practice ( $3^{\text {rd }}$ ed.). London: Sage Publication.

Pape, L. (2010). Blended teaching and learning. School Administrator, 67(4), 16-21.

Per, D., \& Kitson, K. (2004). School development: Theories and strategies. Bloomsbury Academic.

Rieley, J. B. (2020). Coronavirus and its impact on higher education. https://www.researchgate.net/post/Corona_Virus_and_its_impact_on_higher_education

Scardamalia, M. (2002).Collective cognitive responsibility for the advancement of knowledge.In B. Smith (Ed.).Liberal education in the knowledge age (pp. 67-98).Chicago: Open Court.

Serhan, D. (2020). Transitioning from face-to-face to remote learning: Students' attitudes and perceptions of using Zoom during COVID-19 pandemic. International Journal of Technology in Education and Science (IJTES), 4(4), 335-342.

Shrestha, S. (2018, Sep 7). ICT in education. The Kathmandu Post. https://kathmandupost.com/opinion/2018/11/07/ict-in-education

Somekh, B., \& Davis, M. (Eds.). (1999). Using information technology effectively in teaching and learning. London: Routledge.

Stern, J. (n.d.). Introduction to online teaching and learning. http://www.wlac.edu/online/documents/otl.pdf

Sun, A., \& Chen, X. (2016). Online education and its effective practice: A research review. Journal of Information Technology Education: $\quad$ Research, $157-190$. http://www.informingscience.org/Publications/3502

The Kathmandu Post ( 2020 September 18). Nepal records highest single-day spike in coronavirus cases with more than 2,000 new infections. https://kathmandupost.com/health/2020/09/18/nepal-records-highestsingle-day-spike-in-coronavirus-cases-with-more-than-2-000-new-infections

TU (2020). Online class nirdesika. www.tu.edu.np

Tucker, B. (2007). Laboratories of reform: Virtual high schools and innovation in public education. (Education Sector Reports) http://heartland.org/sites/all/modules/custom/heartland_migration/files/pdfs/28154.pdf

Tümen Aky1ldı, S. (2020). College students' views on the pandemic distance education: A focus group discussion. International Journal of Technology in Education and Science (IJTES), 4(4), 322-334.

TUODEC. (2015).Introduction. http://www.odectu.edu.np/

U.S. Department of Education (2010). Evaluation of evidence-based practices in online learning: A metaanalysis and review of online learning studies. www.ed.gov/about/offices/list/opepd/ppss/reports.html

UNESCO (2020). Covid-19 impact on education data. COVID-19 education disruption and response. The United Nations Educational, Scientific and Cultural Organization, UNESCO. Paris, France. 
Unger, S., \& Meiran, W. R. (2020). Student attitudes towards online education during the COVID-19 viral outbreak of 2020: Distance learning in a time of social distance. International Journal of Technology in Education and Science (IJTES), 4(4), 256-266.

UNO (2020 August). Education during COVID-19 and beyond. The United Nations Educational, Scientific and Cultural Organization, UNESCO. Paris, France.

\section{Author Information}

\section{Pitambar Paudel}

Orcid: https://orcid.org/0000-0001-5706-170X

Tribhuvan University

Prithvi Narayan Campus

Pokhara

Nepal

Contact e-mail: pitambarp@pncampus.edu.np 


\section{Appendix A. Survey}

\section{Dear Sir/ Madam}

CovID-19 has shifted our teaching and learning process from only face to face to online mode. Online mode teaching and learning is probably new practice in our context. I am trying to carry out a research on Online Education: Benefits, Challenges and Strategies in Higher Education of Nepal. I kindly request you to participate in the research and give your response honestly which can be great contribution in this research.

* Required

Email address *

Your email

\section{Questions related to the advantages of online learning}

Choose from the answers 1 to 15 to complete the questions. You may choose ONE or MORE answers

What are the benefits of the online class? *

1. Online courses are convenient.

2. Online courses allow me to work in my own pace.

3. Online courses offer flexibility.

4. Online courses take me in the huge resource of knowledge

5. Online courses bring education right to my home.

6. Online courses increase independency in learning

7. Online courses offer more individual attention.

8. Online courses help me meet interesting people.

9. Online courses give me real world skills.

10. Online courses promote life-long learning.

11. Online courses have financial benefits.

12. Online courses teach me to be self-disciplined.

13. Online courses help me in promoting online research and resources.

14. Online courses connect me to the global village

15. Online courses provide updated and authentic information

\section{Questions related to the problems/challenges that you have faced}

Choose from the answers 1 to 15 to complete the questions. You may choose ONE or MORE answers

\section{What are the challenges/problems in online education (teaching/learning)? *}

1. Online courses require more time than on-campus classes.

2. Online courses require good time-management skills.

3. Online courses may create a sense of social isolation.

4. Online courses allow me to be more interdependent to the resources

5. Online courses make me lazy.

6. Online courses don't have an instructor hounding me to stay on task.

7. Online courses give me more freedom, perhaps, more than I can handle!

8. Online courses require that I must find my own path to learning.

9. Online courses provide limited and delayed feedback

10. Online courses requires reliable internet at home

11. Online courses increase habit of plagiarism/cheating

12. Meeting the deadline for submitting task

13. Online courses do not promote practice-based learning

14. Online Courses are limited to certain discipline

15. Online courses cannot enhance accreditation and quality in learning 


\section{Questions related to the characteristics required for online education}

Choose from the answers 1 to 10 to complete the questions. You may choose ONE or MORE answers

\section{What qualities/characteristics are required for online education? *}

1. Good work ethics

2. Time management skills

3. Independent and responsible

4. Goal oriented

5. Self-motivated

6. Effective communicator

7. Personal commitments

8. Computer Literate

9. Academic Readiness

10. Technologically Prepared

\section{Questions related to your future strategies and recommendations}

This is a set of subjective questions. Please spend some time and respond them which may bring new wave in online education of Nepal.

1. Would you take an online course in the future? Why or why not? *

2. What is the youngest age student should be allowed to participate in online courses? *

3. What advice would you give to an instructors/ students who are planning on setting up and Instructing an online course? $*$

4. What suggestions would you make to the policy makers/course designers regarding online education practices in education of Nepal? ${ }^{*}$

5. Does online education need integration of face-to-face interaction for more effective implementation and results? Explain. * 